\title{
ANALISIS STRATEGI PENGEMBANGAN PRODUKSI GULA MERAH CAIR PADA IKM GULA MERAH CAIR DENGAN MENGGUNAKAN METODE QFD
}

\author{
${ }^{1)}$ Ahmad Hanafie, ${ }^{2)}$ Musrawati, ${ }^{3)}$ Asti \\ ${ }^{1,2)}$ Dosen Program Studi Teknik Industri Fakultas Teknik Universitas Islam Makassar \\ ${ }^{3)}$ Mahasiswi Program Studi Teknik Industri Universitas Islam Makassar \\ Jl. Perintis Kemerdekaan Km 9 No 29 Kampus UIM, Telp 0411-588-167 \\ Email : ${ }^{1)} \frac{\text { ahmadhanafie.dty@ uim-makassar.ac.id, }}{\left.{ }^{2}\right)} \underline{\text { Musrawaati@gmail.com, }}$
}

\begin{abstract}
ABSTRAK
Quality Function Deployment (QFD) merupakan pendekatan interaktif sektor industri untuk menilai kebutuhan konsumen sebelum perancangan produksinya dilakukan, elemen dasar pengukuran QFD menekankan perancangan produk atau jasa guna kebutuhan dan kepuasan konsumen termasuk menganalisa kinerja produk untuk memenuhi kepuasan konsumen dan mengurangi banyaknya perubahan desain. Penelitian ini mengimplementasikan konsepsi tersebut untuk mengkaji pengembangan atribut-atribut pelayanan yang diprioritaskan untuk meningkatkan kualitas pelayanan basis pengguna. Pada penelitian ini metode QFD dilakukan sampai dengan 3 fase yaitu untuk mencoba mengetahui atribut-atribut produk yang diinginkan konsumen, tingkat kepentingan, tingkat kepuasan konsumen, parameter teknik, kebutuhan proses dan prosedur kualitas. QFD diaplikasikan untuk menterjemahkan apa yang diinginkan oleh konsumen ke dalam prosedur kualitas yang lebih terperinci, jelas, teknis dan operasional untuk menjawab smua kebutuhan dari konsumen. Hasil dari penelitian pada IKM Gula Merah Cair dengan menggunakan metode QFD, didapatkan 10 atribut produk yang diinginkan oleh konsumen dan diterjemahkan ke dalam 11 parameter teknik dalam House of Quality (HOQ) tahap 1, dari hasil HOQ ini didapat 4 buah atribut produk yang akan dikembangkan yaitu atribut Nama Produk, Tekstur, Desain Kemasan, dan Logo Produk. Matrik HOQ tahap 2 menggambarkan bagaimana 11 parameter teknik tersebut dijabarkan menjadi 7 kebutuhan proses pembuatan gula merah cair hal ini dilakukan untuk mengetahui prioritas utama kebutuhan proses dalam pembuatan gula merah cair. Setelah HOQ Tahap 2 dilakukan maka langkah selanjutnya adalah pembuatan Production Planning Matrix sebagai standar operasional prosedur pembuatan gula merah cair.
\end{abstract}

Kata kunci : HOQ, Gula Merah Cair, Pelanggan, Produk, QFD

\section{PENDAHULUAN}

\subsection{Latar Belakang}

Kabupaten Jeneponto adalah salah satu Kabupaten di Sulawesi Selatan yang memiliki nilai potensial pengolahan atau pemanfaatan nira Lontara yang menjanjikan, terutama disektor pengolahan nira Lontara menjadi gula merah. Lontara atau siwalan (Borassus flabellifer) adalah jenis palma yang serba guna. Hampir semua bagian tumbuhan ini bermanfaat bagi umat manusia, antara lain sebagai bahan pangan, bangunan, perabot rumah tangga dan barang kesenian dan budaya (Mahmud dan Amrizal1991).

Untuk meningkatkan pemanfaatan nira Lontara di Kabupaten Jeneponto, perlu diperlukan penelitian sehingga bahan baku ini dapat diolah untuk menghasilkan produkproduk baru bernilai ekonomis. Dengan melihat potensi gula merah yang terdapat di Kabupaten Jeneponto, penulis berinisiatif 
untuk mengembangkan produksi gula merah cair di Kabupaten Jeneponto.

Pengembangan produk sebaiknya menggunakan metode yang terstruktur (Ulrich, 2001). Pengembangan produk harus diawali dengan identifikasi kebutuhan pelanggan bertujuan untuk mengetahui atribut-atribut yang penting dan berhubungan dengan kepuasan pelanggan sebagai dasar dalam langkah pengembangan produk selanjutnya.

\subsection{Rumusan Masalah}

Adapun yang menjadi permasalahan dalam penelitian ini adalah:

1. Bagaimana Pengembangan Produksi Gula Merah Cair Pada Industri Kecil Menengah (IKM) dengan Menggunakan Metode QFD

2. Bagaimana Kualitas Produksi Gula Merah Cair di Industri Kecil Menengah (IKM) Gula Merah Cair di Kabupaten Jeneponto.

\subsection{Tujuan Penelitian}

Adapun yang menjadi tujuan dalam penelitian ini adalah:

1. Untuk Mengetahui Pengembangan Produksi Gula Merah Cair Pada Industri Kecil

2. Menengah (IKM) dengan Menggunakan Metode QFD

\section{METODOLOGI PENELITIAN}

\subsection{Tempat Penelitian}

Penelitian dilakukan di Jl. Abd Sikki BTN Romanga Kecamatan Binamu Kabupaten Jeneponto, dengan pertimbangan bahwa di kabupaten jeneponto tersebut mempunyai pohon lontara yang sangat banyak dibandingkan dengan kabupaten lainnya.

\subsubsection{Rancangan Survei dan Validitas data Penelitian}

Data diperoleh dengan metode survei, observasi dan wawancara. Data terdiri dari dua macam yaitu data primer dan sekunder. Data primer berupa hasil pengamatan dan hasil kuesioner rehadap pengguna produk gula merah cair, sedangkan data sekunder diperoleh melalui literatur. Kuesioner dibagikan kepada responden masyarakat kabupaten jeneponto dengan metode sampel untuk mengetahui tingkat kepentingan setiap karakteristik pengguna produk gula merah cair. Dalam pengambilan data tingkat kepentinga, kepuasan, dan kepuasan yang diharapkan menggunakan skala Likert.

\subsubsection{Tahap Membangun Rumah Kualitas}

Pada tahap ini membangun rumah kualitas ada lima tahap yang perlu dilakukan yaitu voice of customer, matriks perencanaan, penentuan respon teknis, penentuan matriks hubungan dan prioritas, analisa dan interpretasi.

Tabel 1. Atribut Produk gula merah cair (customer needs)

\begin{tabular}{ll}
\multicolumn{2}{c}{ Customer Requirement (Whats) } \\
& \\
\hline Produk & Rasa \\
Produk & Aroma \\
Produk & Warna \\
Produk & Tekstur \\
Produk & Hieginis \\
Produk & Nama produk \\
Produk & Logo produk \\
Produk & Harga \\
Produk & Desain kemasan \\
Produk & volume kemasan \\
\hline
\end{tabular}

Tabel 2. Respon Teknis

\begin{tabular}{ll}
\hline No & Respon Teknis (Hows) \\
\hline 1 & Memilih Nira Lontar Yang baik \\
2 & Mengatur kadar Garam \\
3 & Kadar PH \\
4 & Kebersihan Alat \\
5 & Hieginis Karyawan \\
6 & Proses penyaringan \\
7 & Menerapkan GMP pada IKM \\
8 & Kesterilan bahan \\
9 & Penambahan bahan pengawet \\
10 & Proses pengemasan \\
11 & Bahan dan model kemasan \\
\hline
\end{tabular}

\section{ANALISA DAN PEMBAHASAN}

Dalam penelitian atribut-atribut tersebut dikelompokkan dalam suatu tabel, tabel tersebut adalah dapat dilihat pada tabel 4 . Hasil atribut produk gula merah cair yang diinginkan konsumen (customer need). Atribut-atribut tersebut merupakan kebutuhan 
konsumen produk gula merah cair yang ada di kabupaten jeneponto, diantaranya tingkat kepentingan, tingkat kepuasan yang dirasakan dan tingkat kepuasan yang diharapkan.

Tabel 3. Hasil atribut produk gula merah cair (customer needs)

\begin{tabular}{llccc}
\hline $\begin{array}{c}\text { N } \\
\text { o }\end{array}$ & Atribut & $\begin{array}{c}\text { Tingkat } \\
\text { Kepenting } \\
\text { an }\end{array}$ & $\begin{array}{c}\text { Tingkat } \\
\text { Kepuasan }\end{array}$ & $\begin{array}{c}\text { Tingkat } \\
\text { Yang } \\
\text { diharap } \\
\text { kan }\end{array}$ \\
\hline 1. & Rasa & 4,221 & 2,400 & 4,347 \\
2. & Aroma & 4,179 & 2,389 & 4,295 \\
3. & Warna & 4,021 & 2,379 & 4,316 \\
4. & Tekstur & 4,116 & 2,442 & 4,242 \\
5. & Hieginis & 4,095 & 2,453 & 4,263 \\
6. & Nama & 4,158 & 2,463 & 4,232 \\
& produk & & & \\
7. & Logo & 4,168 & 2,432 & 4,284 \\
& produk & & & \\
8. & Harga & 4,189 & 2,421 & 4,253 \\
9. & Desain & 4,137 & 2,474 & 4,358 \\
& kemasan & & & \\
10 & Volume & 4,147 & 2,495 & 4,747 \\
. & kemasan & & & \\
\hline
\end{tabular}

Dari hasil penelitian responden tingkat kepentingan tersebut seperti terlihat pada tabel 3, kesepuluh atribut menyatakan persepsi responden pada skala 4,021-4,189 yang artinya cukup penting dan sangat penting pada produk gula merah cair. Pada tingkat kepuasan responden menyatakan persepsi kesepuluh atribut pada skala 2,379 2,400 yang artinya kurang memuaskan dalam menggunakan produk gula merah cair. Sedangkan kepuasan yang diharapkan responden dengan skala 4,747 - 4,347 yang artinya responden mengharapkan adanya perbaikan pada produk gula merah cair.

\section{PENUTUP}

\subsection{Kesimpulan}

Dari hasil pengembangan produksi gula merah cair pada industri kecil menengah (IKM), atribut-atribut yang diprioritaskan pertama adalah bahan dan model kemasan dengan nilai prioritas 3,640, kedua memilih nira lontar yang baik dengan nilai prioritas
3,092, ketiga menerapkan GMP pada IKM dengan nilai prioritas 2,268, keempat kadar PH dengan nilai prioritas 2,558, kelima proses pengemasan dengan nilai prioritas 2,554, keenam penambahan bahan pengawet dengan nilai prioritas 2,075, ketujuh hieginis karyawan dengan nilai prioritas 2,006, kedelapan kebersihan alat dengan nilai prioritas 1,628, kesembilan kesterilan bahan kemasan dengan nilai prioritas 1,613, kesepuluh proses penyaringan dengan nilai prioritas 1,426, kesebelas mengatur kadar garam dengan nilai prioritas 1,232.

Peningkatan kualitas produk yang sesuai dengan keinginan konsumen yaitu pertama adanya bahan dan model kemasan yang menarik konsumen agar tertarik membeli produk kita, kedua memilih nira lontar yang baik agar produk yang dihasilkan kualitas dan mutunya terjamin, ketiga menerapkan GMP pada IKM agar kebersihannya terjamin, keempat memilih nira lontar yang kadar $\mathrm{PH}$ nya tidak melebihi dari standar yangditerapkan dan mengurangi terjadinya proses pencoklatan atau browning pada saat pemasakan nira, kelima Proses pengemasan harus benar-benar kuat dan packingnya lebih bagus sehingga produk gula merah cair mampu bersaing di pasaran, keenam perlu adanya penambahan bahan pengawet agar produk gula merah cair mampu bertahan lama, ketujuh hieginis karyawan sangat diperlukan agar bahan-bahan tidak terkontaminasi dengan bahan yang lain, kedelapan perlu adanya kebersihan alat agar produk gula merah cair lebih terjamin mutu dan kualitasnya, kesembilan kesterilan bahan kemasan agar tidak ada serangga-serangga atau kotoran berada diproduk gula merah cair, kesepuluh perlu adanya proses penyaringan agar kotoran-kotoran atau sisa-sisa bekas pengadukan tidak tercampur pada saat produk dimasukkan dalam kemasan, kesebelas mengatur kadar garam agar produk gula merah cair tidak terlalu manis dan pekat.

\section{DAFTAR PUSTAKA}

Ahmad Hanafie, Hammada Abbas, Lawalenna Samang, Sumarni Hamid, (2014), Kajian Utilitas Kendaraan Dan 
Fasilitas Pemberhentian Angkutan Kota Yang Bernilai Ekonomi, Publikasi Ilmiah Proposal Penelitian S3 Teknik Sipil Unhas, Vol. April 2014,ISSN:2087-7986

Ahmad Hanafie, Hammada Abbas, Lawalenna Samang, Sumarni Hamid, (2014), Kajian Utilitas Kendaraan Angkutan Kota Yang Bernilai Ergonomi. Proceding Seminar Nasional Teknologi Industri II ATIM 2014,ISBN 978602-14822-1-6. Hal. 307-310

Amin, Idi. 2012. Ekonomi Teknik Bahan Ajar. Akademi Teknik Industri Makassar. Makassar

Anonim.2010 Pengembangan-produkkonsumen-dengan http: // wordskripsi .blogspot. com / 2010 04/037. html. Diakses tanggal 20/5/2015.

BPS Kabupaten Jeneponto. Htpp://jenepontokab.bps.go.id/ [15 juni 201420.25 wita]

Cohen L, (1995), Quality Function Deplyment, How to Make QFD Work for You Addition Wesley -Publishing Company, Reading, Massachusetts, 1995.

Gyerie. 2009. Manfaat Gula Merah Untuk Kesehatan.

(Online) http:/bloggyerie.blogspot,com/2011/07/m anfaat-gula-merah-untuk-kesehatankita.html. Diakses 20 agustus 2013.

Heyne, K. 1987. Tumbuhan Berguna Indonesia. Jilid 1.Penerbit Yayasan Sarana WanaJaya. Jakarta.

Http://merlitafutriana0.blogspot.com/p/validit as-dan-realibilitas.html

Http://abume.wordpress.com/category/teknikindustri/pengembangan produk

Joseph, G.H.M.M, M. Rumokoi dan Z. Mahmud. 1990. Perbaikan teknik penyadapan nira lontar di Nusa tenggara Timur. Buletin Balitka No. 11 Thn 1990 hlm. 103-111, Balai Penelitian kelapa. Manado.

Kotler, $\quad$ Philip., Keller, Kavin Lane.2009.Manajemen Pemasaran Ed.Ke-13 Jilid 1. Jakarta: Erlangga.

Noviana, M., Hastanto, S., "Penerapan Metode Quality Function Deployment
(QFD) untuk Pengembangan Desain Motif Batik Khas Kalimantan Timur", J@TI Undip, Vol. IX, No. 2, pp 87-92,s 2014

Wagiyono.2003.Menguji Kesukaan Secara organeleptik.Jakarta

Winarno.2002 Kimia Pangan dan Gizi. Gramedia Pustaka Utama, Jakarta. 